\title{
The Information-Technology Revolution and the Stock Market
}

\author{
By JEREMY GREENWOOD AND BOYAN JOVANOVIC*
}

Technological progress comes in waves. The British Industrial Revolution (17601850 ) ushered in Cort's puddling and rolling process for making iron, Crompton's mule for spinning cotton, and the Watt steam engine. The Second Industrial Revolution (18901930) witnessed the rise of electricity, the internal-combustion engine, and the chemical industry. The birth of information technology (IT) may herald the start of a Third Industrial Revolution.

A new technology or product is often developed by the single entrepreneur who initially finds it hard to get funds, develop the product, and find customers. But if the product is good, customers eventually line up, and investors flock in. Other firms then move in to make the product and may drive the innovator out or acquire him. Whether he reaches the initial public offering (IPO) stage or is acquired by a listed firm, though, it takes time for the innovator to add value to the stock market. Indeed, the innovation may, at first, reduce the market's value because some firms, usually large or old, will cling to old technologies that have lost their momentum.

Figure 1 plots the market value of U.S. equity relative to GDP. This paper argues that (a) the market declined in the late 1960's because it felt that the old technologies either had lost their momentum or would give way to IT, and that (b) IT innovators boosted the stock market's value only in the 1980's. If the stock market provides a forecast of future events, then the recent dramatic upswing represents a rosy estimate about growth in future profits for the economy. This translates into a forecast of higher output and productivity growth, holding other things equal (such as capital's share

\footnotetext{
* Department of Economics, University of Rochester, Rochester, NY 14627, and Department of Economics, New York University, New York, NY 10003, respectively. Rajshree Agarwal, Bart Hobijn, Samuel Kortum, $\mathrm{Li} \mathrm{Li}$, and Masako Ueda are thanked for their help.
}

of income). To prepare for the main argument, a few words, first, on the IT industry prior to the late 1960's.

\section{The Rise of Centralized Computing}

The first business computer was the UNIVAC, built by John Eckert, an electrical engineer, and John Mauchly, a physicist. In 1946 they started the Electronic Control Company. There were no venture-capital companies in those days, so they peddled the idea of a computer to customers. They sold one to the Census Bureau for $\$ 300,000$, and one each to A. C. Nielsen and Prudential Insurance Company for $\$ 150,000$. American Totalisator generously bought 40 percent of the fledging company for $\$ 500,000$. Developing the UNIVAC turned out to cost far more than the estimated $\$ 400,000$. Eckert and Mauchly were soon in a desperate financial situation, and in 1950 they sold out to Remington Rand, an office-machine company, which promptly reneged on the deals with A. C. Nielsen and Prudential, knowing that they would suffer a loss at any price below $\$ 500,000$. By 1951 the 5,000-tube UNIVAC was running at the Census. UNIVAC (now a division of Remington Rand) predicted the results of the 1952 presidential election on CBS television. The UNIVAC technology was very expensive. In the early 1950's, UNIVACs were selling for $\$ 1,000,000$.

UNIVAC's launch at the Census was a wake-up call to another office-machine manufacturer, IBM, headed by Thomas Watson, Sr., a former cash-register salesman. Watson knew that products had to be customer-friendly to sell. So, IBM quickly offered training courses for users and field engineering teams for service. IBM's computers were also modular in design, with components that could fit in elevators. (The early UNIVAC was a giant.) By 1955, IBM was selling more computers than UNIVAC, but in the early 1960's, 65 percent of IBM's 


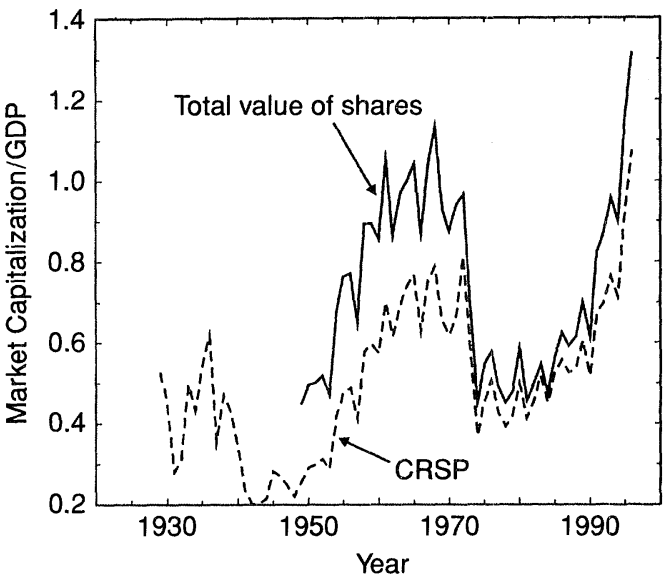

Figure 1. Stock-Market Value Relative to GDP

revenue still came from office machines. It had 100,000 employees and annual sales of $\$ 1.8$ billion. By the end of the 1960's there were 80,000 computers in the United States and 50,000 elsewhere. IBM's market share of computer sales was 70 percent. Its annual sales were $\$ 7.2$ billion, and it employed 259,000 people. But its dominance would soon give way to the minicomputer in the 1970's and to the microcomputer (now called the personal computer or PC) in the 1980's.'

\section{Why Did the IT Revolution Favor New Firms?}

A technological breakthrough favors new firms for three reasons.

1. Awareness and Skill. - The manager of an old firm may not know what the new technology offers or may be unable to implement it. When IBM entered the PC world in 1980, it needed an operating system for its new product. Lacking the skill to develop one quickly, IBM approached Gary Kildall of Data Research, but he turned them down. IBM then turned to Microsoft. The royalty that Micro-

\footnotetext{
${ }^{1}$ Sections I and V are based on Martin Campbell-Kelly and William Aspray (1996).
}

soft earned on each copy of MS-DOS sold propelled it into the big leagues. Surely, Gary Kildall was unaware of the opportunity he was turning down.

2. Vintage Capital. - An old firm's human and physical capital is tied to its current practices, and it may not easily convert to new technology. It sometimes is irrational to abandon a huge investment in an older technology and move to a new one. Unencumbered by the past, a new firm will have more incentive to adopt new methods immediately. Around 1890 , the early adopters of electricity were expanding industries with high net investment, such as fabricated metal, transportation, and equipment. Elsewhere, water and steam power hung on.

3. Vested Interests. - Management and workers in an older firm, especially if they belong to a union, may resist new technology because it devalues their skills. In doing so, they harm the interests of the firm's shareholders, lowering the value of the firm, and even may threaten its very survival.

\section{The Model}

The model is the Robert Lucas (1978) exchange economy populated by many infinitely-lived identical agents and equally many infinitely-lived trees. A perfectly foreseen consumption stream $\left\{y_{t}\right\}_{t=0}^{\infty}$ would yield its consumer a lifetime utility of $\Sigma_{t=0}^{\infty} \beta^{t} U\left(y_{t}\right)$. The date-zero price of a tree that promised a stream of dividends $\left\{d_{t}\right\}_{t=0}^{\infty}$ would be $\sum_{t=0}^{\infty}$ $\beta^{t}\left[U^{\prime}\left(y_{t}\right) / U^{\prime}\left(y_{0}\right)\right] d_{t}$.

A tree yields one unit of output in each period, forever. The output goes to the tree's owners as a "dividend." If agents expected the status quo to persist forever, each would expect $d_{t}=1$ for all $t$, and the date-zero share price of each tree would then be

$$
P_{0} \equiv \sum_{t=0}^{\infty} \beta^{t} \frac{U^{\prime}(1)}{U^{\prime}(1)}=\frac{1}{1-\beta} .
$$

Then, $P_{0}$ would also be the tree's price-earnings ratio, and the ratio of the stock market's value to output. 


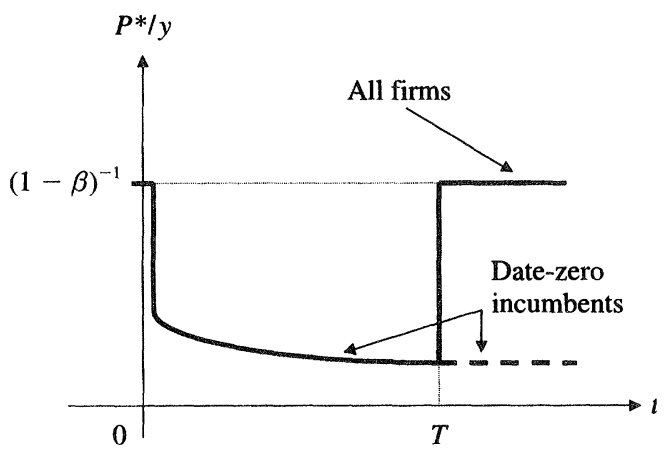

Figure 2. Stock-Market Value Relative TO GDP, PREDICTED

Unexpectedly, news arrives at $t=0$ that a fraction $x$ of existing trees will die at the beginning of date $T$. They will be replaced, instantaneously, by equally many new, better trees, each yielding $1+z$ units of output, where $z>0$. The lifetime of each tree (either $T$ or $\infty$ ) is also announced at date zero. (This assumption has no implications for the aggregate stock market.) The new trees will not trade on the stock market until date $T$, when their ownership is allocated equally among agents. No technology shocks are expected to occur ever again.

At date $T$, per capita output rises permanently to $1-x+x(1+z)=1+x z$. That is,

$$
y_{t}= \begin{cases}1 & \text { for } t \leq T-1 \\ 1+x z & \text { for } t \geq T\end{cases}
$$

Before period $T$, two different types of tree trade on the stock market, and each loses value when the news of the technology shock arrives.

1. A Type-1 Tree (Dies at T). - Its date-T liquidation value is zero. Before then, its shares sell for

$$
P_{1, t}=\frac{1-\beta^{T-t}}{1-\beta}
$$

2. A Type-2 Tree (Lasts Forever). - Its expected dividend stream is unchanged. Its shares sell for

$$
\begin{aligned}
P_{2, t} & =P_{1, t}+\sum_{\tau=T-t}^{\infty} \beta^{\tau}\left(\frac{U^{\prime}(1+x z)}{U^{\prime}(1)}\right) \\
& =P_{1, t}+\frac{\beta^{T-t}}{1-\beta}\left(\frac{U^{\prime}(1+x z)}{U^{\prime}(1)}\right) .
\end{aligned}
$$

Such a tree loses value because the fruit it bears beyond date $T$ is now discounted at a higher rate.

Before $T$, stock-market value is a weighted average of the two types of trees:

$$
\begin{aligned}
P_{t} & \equiv x P_{1, t}+(1-x) P_{2, t} \\
& =P_{1, t}+\frac{(1-x) \beta^{T-t}}{1-\beta}\left(\frac{U^{\prime}(1+x z)}{U^{\prime}(1)}\right) .
\end{aligned}
$$

Evidently, larger values of $x$ and $z$ raise consumption, while a larger value of $T$ lowers it. In sharp contrast, $x$ and $z$ both act to lower $P_{t}$, while a higher $T$ raises it! First, $P_{t}$ is decreasing in $x$; some trees are expected to be replaced by trees that are not yet in the market portfolio, so its value falls. Moreover, a rise in $x$ also lowers $P_{t}$ by raising the interest rate. Second, $P_{t}$ is decreasing in $z$, a pure interest-rate effect: consumption rises at $T$, and subsequent dividends are discounted at a higher rate. Third, a rise in $T$ raises $P_{t}$ (through $P_{1, t}$ ).

At date $T$ the new trees become productive and start to be traded. Consumption and dividends then rise permanently to $1+x z$. From then on, the stock-market value is $(1+x z) /$ $(1-\beta)$. Letting $P_{t}^{*}$ denote the stock market's value at date $t$

$$
P_{t}^{*}= \begin{cases}P_{t} & \text { for } t \leq T-1 \\ \frac{1+x z}{1-\beta} & \text { for } t \geq T .\end{cases}
$$

The counterpart of Figure 1 is the ratio $P_{t}^{*} / y_{t}$, plotted in Figure 2. The two figures look similar if the date $t=0$ is set to correspond to the year 1968, and if $T=20$ years. This seems like a long time, when these days, the average company waits 2.5 years to get venture-capital funding (Thomas Hellman and Manju Puri, 1998), and another four years to 


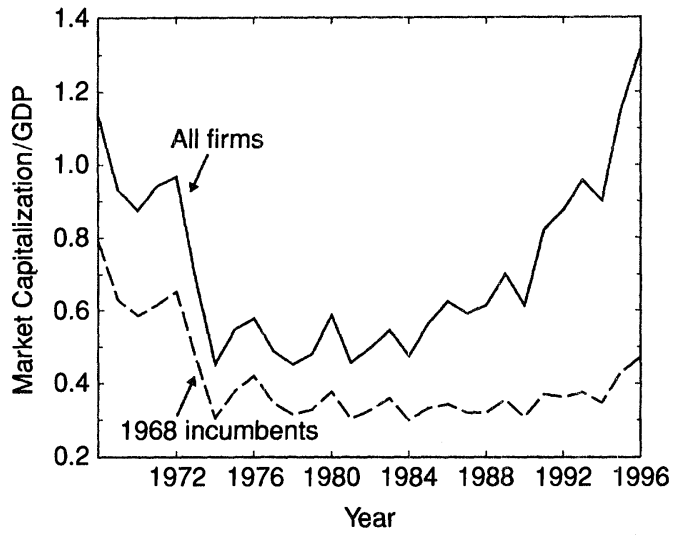

Figure 3. The Fall of the 1968 InCumbents

its IPO (Joshua Lerner, 1994). But the process took longer when IT was young: the biggest player in the IT revolution, Microsoft, was formed in 1976 by Paul Allen and Bill Gates under the name Micro-Soft, but it went public only in 1986. (The effects of technological progress on the stock market are also analyzed in Jovanovic and Glenn MacDonald [1994], Greenwood and Mehmet Yorukoglu [1997], and Elhanan Helpman and Manuel Trajtenberg [1998]; see figs. 4, 16, and 3.6 in these papers, respectively.)

To evaluate the model more carefully, one must ask the following two questions:

(i) How did stock-market incumbents (the "dinosaurs") fare since 1968 ?

(ii) How much value was later added by entrants, and, if so, when?

The answers are provided first for the aggregate, and then for the IT sector.

\section{The Fate of the 1968 \\ Stock-Market Incumbents}

Most stock-market incumbents are identifiable from the Center for Research in Security Prices (CRSP) data. The dashed line in Figure 1 is the market value of firms in the CRSP, which now encompasses all but those firms whose shares trade over the counter. In 1968, it included most big firms. Figure 3 shows that

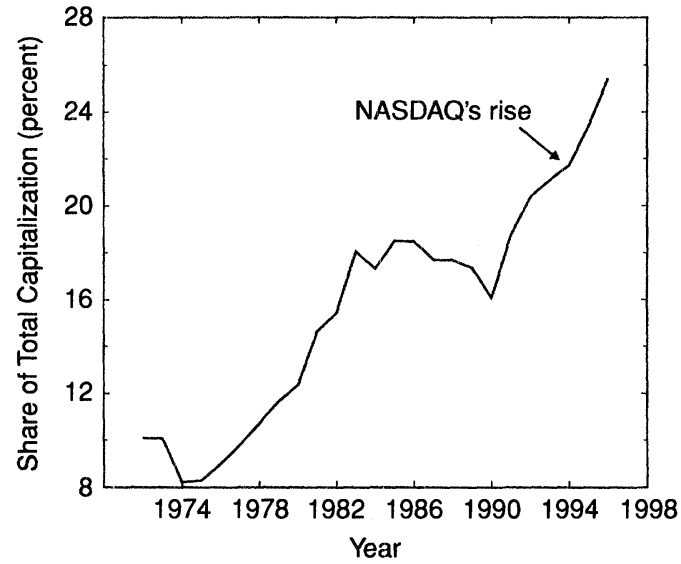

Figure 4. The RISE OF THE NASDAQ FIRMS

the 1968 CRSP incumbents' value fell more than threefold over a few years and never recovered. Yet since 1985 the market has tripled! The source of this new value must, therefore, be firms that entered after 1968, roughly as Figure 2 asserts. A high-tech subset of the post-1968 entrants are the NASDAQ firms, and Figure 4 shows their share in total market capitalization rising sharply.

The 1968 incumbents thus fared rather badly, and entrants did spectacularly well, some 15-20 years later. But did the incumbents do badly relative to other vintages of incumbents? What became of incumbents that, at a corresponding stage in their existence, did not have to cope with technological changes as major as IT? Figure 5 shows that the 1948 incumbents did much better than the 1968 incumbents did: the boom of the 1960's was driven by the rise in values of the 1948 incumbents, whereas the boom of the late 1980's and early 1990's was engineered by firms that entered after 1968. Note that many of the 1948 incumbents grew out of the Second Industrial Revolution, such as IBM (circa 1924).

\section{The Fall of Centralized Computing}

The story applies to the 1968 IT incumbents as well, and with such great force that it is worth telling in detail. The mainframe computer manufacturers of the 1950's and 1960's began to see the tide change by the 1970's. 


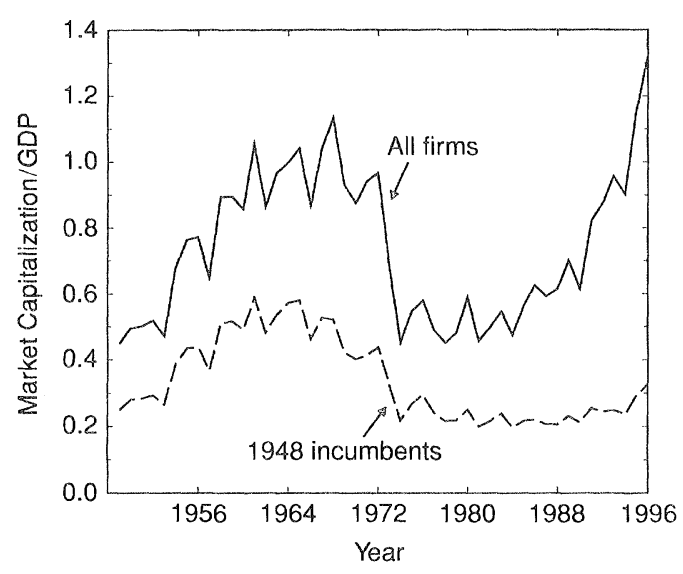

Figure 5. The Fate of the 1948 Incumbents

Digital Equipment Corporation (DEC) was formed in 1957 with the help of $\$ 70,000$ from American Research and Development, headed by the father of venture capital, George Doriot. DEC turned out its first minicomputer, the PDP-1, in 1960. It sold for $\$ 125,000$, which was somewhere between 10 percent and 20 percent of the cost of a mainframe. DEC went public in 1966. By 1970, DEC was the third largest computer manufacturer. Doriot's original investment was worth $\$ 350,000,000$ in 1972. This was nothing compared with the tsunami that was about to hit the industry.

The tsunami rippled quickly through time and space, quietly at first. In 1975 Micro Instrumentation Telemetry Systems introduced a kit for the electronic hobbyist. It was a personal computer called the Altair 8800 . It sold by mail order for $\$ 397$. It did not do much, but it spawned a market for computer hobbyists. Out of this market grew Apple Computer, formed by Steve Jobs and Stephen Wozniak. In 1976, they secured some venture capital to develop the Apple II personal computer. Apple Computer employed fewer than a dozen people at this time. The Apple II was launched the next year. It was an immediate success. Another watershed, in 1972, was the first International Conference on Computer Communications. The 40 terminals at the conference were hooked up to a dozen computers, from Cambridge, MA, to Paris. This

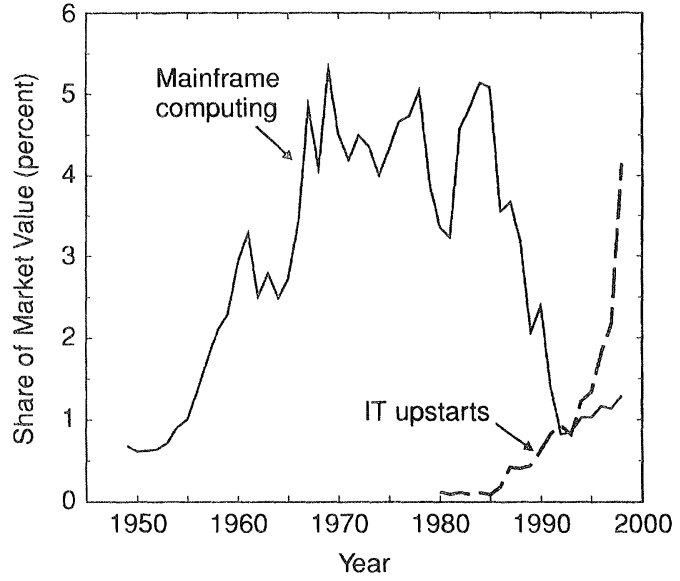

FIgURE 6. WINNERS AND LOSERS IN THE IT INDUSTRY

major event in computer networking marked the dawn of the information superhighway.

Figure 6 plots the rise and fall of mainframe computing. Although dominated by IBM, the industry's other major manufacturers (Burroughs, Honeywell, NCR, and Sperry-Rand) are included. Mainframe manufacturers made their own software early on, but some independent mainframe software contractors such as Computer Associates and Management Services America are added in. Last, some minicomputer manufacturers are included: DEC, Data General, Prime Computer, and Scientific Data Systems. Their share in market value is now a mere fifth of what it was in 1968. The figure also plots the performance of some IT upstarts that were not in the stock market in 1968: four top PC manufacturers (Apple, Compaq, Dell, and Gateway); five leading software companies (Informix, Microsoft, Novell, Oracle, and Peoplesoft); and five internet-service companies (America Online, Infoseek, Lycos, Netscape, and Yahoo). These new companies are now worth nearly four times as much as the old ones!

\section{Entry, Exits, Mergers, and R\&D}

Michael Gort and Steven Klepper (1982) examined 46 product innovations, from phonograph records in 1887, to lasers in 1960. At 


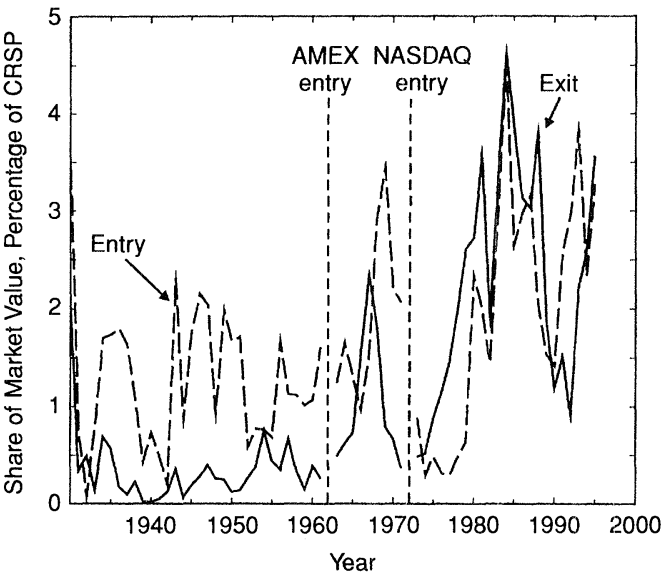

Figure 7. CRSP Entry and Exit in Terms of Value

the time of a product innovation there would usually be just one or two firms in the industry. Then, after some time, a flood of entrants would try to capture some of the monopoly rents. A wave of exits, a "shakeout," would soon follow. Some firms would be forced out by the standardization of the technology that makes mass production possible. Based on this, a technological revolution should cause a dramatic wave of entry and exit. Figure 7 shows that, indeed, since the late 1960's, and especially since the early 1980's, firms entering and exiting the CRSP data account for a larger fraction of its value. Figure 8 reports on exit behavior in 33 product-specific markets ranging in vintage from 1908 to 1992 (Rajshree Agarwal and Michael Gort [1998] describe these data). A firm "exits" a market when it stops making a product. "Size"' is the firm's assets as reported by the Thomas register. Small firms are defined as the lower 60 percent and large firms as the top 40 percent in the size distribution for the decade. Large firms (which are more likely to be traded on the stock market) were more likely to exit in the 1970's than small firms.

One might expect mergers and acquisitions to pick up too. First, some old firms may enter into the new era by acquiring innovators. Second, the process of standardization mentioned above may lead to mergers among the new interests. Third, vested interests that prevent a firm from adopting new methods invite a take-

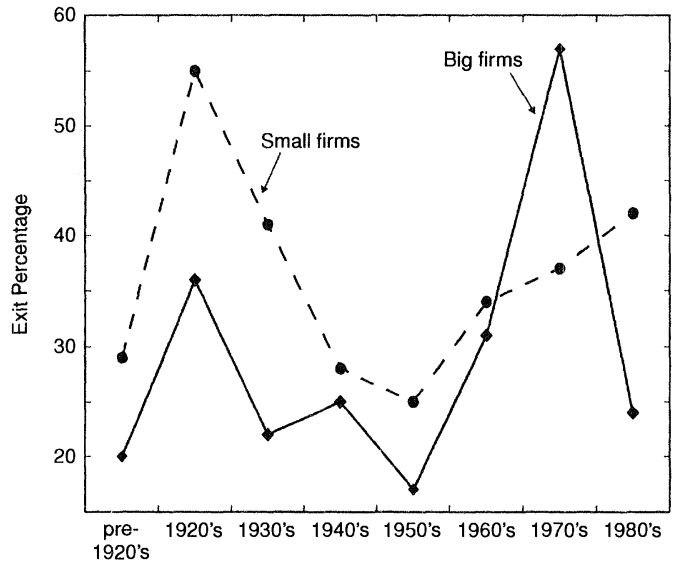

Figure 8. Product-Market Exit

over. The number of mergers did rise sharply in the 1980's and remains high (see fig. 1 in Devra Golbe and Lawrence White, 1993).

In addition to this evidence that replacement has increased in the past two decades, several sources suggest that the pace of technological progress has risen too. In the late 1960's IT made up only 2-3 percent of equipment investment. Today it accounts for more than half. Patent applications by U.S. inventors have almost doubled, from 71,089 in 1970 to 120,445 in 1996 (Samuel Kortum and Lerner, 1998) and R\&D spending by businesses has risen sharply, from 1.0 percent of GDP in 1970 to 1.4 percent in 1996 .

\section{REFERENCES}

Agarwal, Rajshree and Gort, Michael. "First Mover Advantage and the Speed of Competitive Entry 1887-1983.' Mimeo, University of Central Florida, 1998.

Campbell-Kelly, Martin and Aspray, William. Computer: A history of the information machine. New York, Basic Books, 1996.

$\rightarrow$ Golbe, Devra L. and White, Lawrence. " Catch a Wave: The Time Series Behavior of Mergers." Review of Economics and Statistics, August 1993, 75(3), pp. 493-99.

$\rightarrow$ Gort, Michael and Klepper, Steven. "Time Paths in the Diffusion of Product Innovations.', Economic Journal, September 1982, 92(367), pp. 630-53. 
$\rightarrow$ Greenwood, Jeremy and Yorukoglu, Mehmet. $\rightarrow$ Jovanovic, Boyan and MacDonald, Glenn M. "1974.' Carnegie-Rochester Conference "The Life Cycle of a Competitive IndusSeries on Public Policy, June 1997, 46, pp. 49-95. try."' Journal of Political Economy, April 1994, $102(2)$, pp. 322-47.

Hellman, Thomas and Puri, Manju. "The In- $\rightarrow$ Kortum, Samuel and Lerner, Josh. "Stronger teraction between Product Market and Financing Strategy: The Role of Venture Capital." Mimeo, Stanford University, 1998.

Helpman, Elhanan and Trajtenberg, Manuel. "A Time To Sow and a Time To Reap: Growth Based on General Purpose Technologies,' in Elhanan Helpman, ed., General purpose technologies and economic growth. Cambridge, MA: MIT Press, 1998, pp. 55-83. Patent Protection or Technological Revolution: What Is Behind the Recent Surge in Patenting?' Carnegie-Rochester Conference Series on Public Policy, June 1998, 48, pp. 247-304.

Lerner, Joshua. "Venture Capitalists and the Decision To Go Public." Journal of Financial Economics, Spring 1994, 34(3), pp. 293-316.

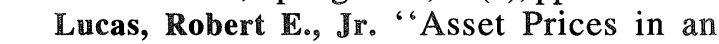
Exchange Economy." Econometrica, November $1978,46(6)$, pp. 1429-45. 